2010-01-01

\title{
The Quays in Salford: an Analysis of Visitor Perceptions, Satisfaction and Behavioural Intention
}

\author{
Ruth Craggs \\ Technological University Dublin, ruth.craggs@tudublin.ie \\ Peter Schofield \\ University of Salford
}

Follow this and additional works at: https://arrow.tudublin.ie/tfschhmtart

Part of the Tourism and Travel Commons

\section{Recommended Citation \\ Craggs, R., Salford, P.:The Quays in Salford: an Analysis of Visitor Perceptions, Satisfaction and Behavioural Intention. International Journal of Tourism Research, 12, 2010. doi:10.1002/jtr.831}

This Article is brought to you for free and open access by the School of Tourism \& Hospitality Management at ARROW@TU Dublin. It has been accepted for inclusion in Articles by an authorized administrator of ARROW@TU Dublin. For more information, please contact arrow.admin@tudublin.ie, aisling.coyne@tudublin.ie, gerard.connolly@tudublin.ie.

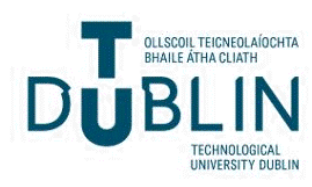




\section{(1) WILEY}

JOHN WILEY \& SONS, LTD., THE ATRIUM, SOUTHERN GATE, CHICHESTER P019 8SQ, UK

*** PROOF OF YOUR ARTICLE ATTACHED, PLEASE READ CAREFULLY ***

After receipt of your corrections your article will be published initially within the online version of the journal.

\section{PLEASE NOTE THAT THE PROMPT RETURN OF YOUR PROOF CORRECTIONS WILL ENSURE THAT THERE ARE NO UNNECESSARY DELAYS IN THE PUBLICATION OF YOUR ARTICLE}

\section{READ PROOFS CAREFULLY}

\section{ONCE PUBLISHED ONLINE OR IN PRINT IT IS NOT POSSIBLE TO MAKE ANY FURTHER CORRECTIONS TO YOUR ARTICLE}

- This will be your only chance to correct your proof

- Please note that the volume and page numbers shown on the proofs are for position only

ANSWER ALL QUERIES ON PROOFS (Queries are attached as the last page of your proof.)

- Please annotate this file electronically and return by email to the production contact as detailed in the covering email. Guidelines on using the electronic annotation tools can be found at the end of the proof. If you are unable to correct your proof using electronic annotation, please list all corrections and send back via email to the address in the covering email, or mark all corrections directly on the proofs and send the scanned copy via email. Please do not send corrections by fax or post.

\section{Acrobat Reader \& Acrobat Professional}

- You will only be able to annotate the file using Acrobat Reader 8.0 or above and Acrobat Professional. Acrobat Reader can be downloaded free of charge at the following address:

http://www.adobe.com/products/acrobat/readstep2.html

\section{CHECK FIGURES AND TABLES CAREFULLY}

- Check sizes, numbering, and orientation of figures

- All images in the PDF are downsampled (reduced to lower resolution and file size) to facilitate Internet delivery. These images will appear at higher resolution and sharpness in the printed article

- Review figure legends to ensure that they are complete

- $\quad$ Check all tables. Review layout, titles, and footnotes

\section{COMPLETE COPYRIGHT TRANSFER AGREEMENT (CTA) if you have not already signed one}

- Please send a scanned signed copy with your proofs by e-mail. Your article cannot be published unless we have received the signed CTA

\section{AUTHOR SERVICES}

- If you have registered this article in Wiley-Blackwell Author Services, the article's status will be updated shortly after you have returned your proof corrections (you will also receive an e-mail alert if you have opted to receive them). You are entitled to free access to the PDF from Author Services when your article is published online. This free access is considered your PDF offprint, and you will only have access from within Author Services; you will not be sent a PDF. You may also nominate up to 10 colleagues for free access. All accesses from Author Services count towards the usage of your article. For options to order print copies or additional electronic access, please see below.

\section{OFFPRINTS}

- $\quad$ Free access to the final PDF offprint of your article will be available via Author Services only. Please therefore sign up for Author Services if you would like to access your article PDF offprint and enjoy the many other benefits the service offers

\section{Additional reprint and journal issue purchases}

- Should you wish to purchase additional copies of your article, please click on the link and follow the instructions provided: http://offprint.cosprinters.com/cos/bw/

- To purchase reprints in smaller quantities, please visit http://www3.interscience.wiley.com/aboutus/ppv-articleselect.html. Restrictions apply to the use of reprints - if you have a specific query, please contact permissionsuk@wiley.com Corresponding authors are invited to inform their co-authors of the reprint options available

- To purchase a copy of the issue in which your article appears, please contact cs-journals@wiley.co.uk upon publication, quoting the article and volume/issue details

- Please note that regardless of the form in which they are acquired, reprints should not be resold, nor further disseminated in electronic or print form, nor deployed in part or in whole in any marketing, promotional or educational contexts without authorization from Wiley. Permissions requests should be directed to permissionsuk@wiley.com 


\section{The Quays in Salford: an Analysis of Visitor Perceptions, Satisfaction and Behavioural Intention}

Ruth Craggs ${ }^{1}$ and Peter Schofield ${ }^{2, *}$

${ }^{1}$ School of Hospitality Management and Tourism, Dublin Institute of Technology, Dublin, Ireland

${ }^{2}$ Salford Business School, University of Salford, Salford, UK

\section{ABSTRACT}

Despite an extensive literature on urban regeneration, visitor perceptions of urban waterfront destinations and their subsequent outcomes remain largely unexplored. The paper reports the findings from a survey of visitors to the Quays in Salford; it focuses on their perceptions, satisfaction and behavioural intentions. While the primary attractions were found to have an important influence, the secondary elements explain more of the variance in overall satisfaction and intention to return to the Quays and the environmental aspects have a greater influence on visitor intention to recommend the destination. The implications of the findings for destination management and marketing are discussed. Copyright (c) 2010 John Wiley \& Sons, Ltd.

Keywords: urban tourism; visitor perceptions; day trips; regression analysis.

Received 14 April 2010; Revised 11 November 2010; Accepted 1 December 2010

\section{INTRODUCTION}

1 There is now an extensive body of literature concerned with urban waterfront regeneration, but visitor perceptions of urban waterfront destinations and their on-site behaviour and experience have been neglected

*Correspondence to: Dr Peter Schofield, Management and Management Sciences Research Institute, University of Salford, Salford M6 6PU, UK.

E-mail: p.schofield@salford.ac.uk
(Van der Knapp and Pinder, 1992; Shaw and Williams, 1994; Craig-Smith, 1995; Selby, 2004). Additionally, while integrated frameworks for the study of urban tourism have been proposed (Tyler, 2000), little is known about urban visitors (Ashworth and Page, 2000; Baker and Page, 2002); not surprisingly, a greater theoretical and methodological understanding of urban tourism has been called for (Pearce, 2001). Numerous studies have examined visitor satisfaction and its influences at holiday/vacation destinations, but visitor satisfaction with redeveloped urban waterfront areas or similar day trip destinations has been under researched.

Residential and commercial developments, including a strong leisure component, have repositioned the Quays in Salford, the former dockland area of the city, from a manufacturing milieu to an area of consumption (Struthers, 2003). The initial phase of this mixed-use regeneration comprised of waterside office construction and high-class residential housing. Subsequent developments have included visitor attractions such as The Lowry Theatre and outlet shopping mall and Imperial War Museum North together with the Metrolink public transport connection. More recently, the $\mathrm{BBC}^{\prime}$ 's announcement of its intention to relocate part of its operations to the Quays provided the catalyst for the MediaCityUK development by the Central Salford Regeneration Company and Salford City Council. Like many other urban waterfront destinations, the Quays attracts some international tourists as well as domestic visitors and residents (Page and Hall, 2002; Ashworth and Page, 2010). There is some evidence that international visitors are now asking for information about the
84 
Quays with the intention of visiting the destination (Salford City Council, personal communication, 2009). However, without the requisite critical mass of major visitor attractions, the main leisure markets for the Quays are currently residents from the sub-region and from elsewhere in the UK, who visit during the daytime and in the evening. Nevertheless, the area's regeneration has had a profound impact on the economy of Salford through visitor expenditure and by attracting economic investment to create jobs in the leisure, hospitality, retail, banking, computing and media sectors (for further details, see Craggs and Schofield, 2009). Additionally, the waterfront development has created a new image for both the former dockland area and the city overall, which has underpinned the city's repositioning strategy. However, as is the case with many regenerated waterfront destinations, no detailed visitor study has been undertaken. This paper addresses these gaps in our knowledge by examining both visitor perceptions of the Quays in Salford with respect to a range of destination attributes and the variation in those perceptions on the basis of visitor sociodemographics and behaviour. It also examines the perceived dimensions of the destination product from the visitor perspective and evaluates their significance in influencing visitor satisfaction and the likelihood of both recommendation to others and revisitation in the near future.

\section{LITERATURE REVIEW}

In the context of urban tourism research, a well-established systems approach, pioneered by Jansen-Verbeke (1986), views the inner city environment as a 'leisure product'. The model illustrates the interrelationship between elements of the inner-city tourism system and the significance of the inner city as a leisure product consisting of 'primary', 'secondary' and 'conditional' elements. The 'primary' elements or attractions include a variety of facilities, which divide the inner city into an 'activity place' and a 'leisure setting'. The 'secondary' elements consist of the supporting facilities and services such as hotels, catering outlets and shopping facilities, which are consumed by tourists during their visit. Finally, the 'conditional' ele- ments are represented by the tourism infrastructure including signposting, parking facilities, transport provision and tourist-specific services such as tourist information centres, which condition the visit. A wide range of empirical studies have confirmed that these elements of the tourism system exist and can influence visitor motivation, destination experience and overall satisfaction.

\section{Factors influencing tourist satisfaction}

A number of studies have examined the influence of various factors on tourist satisfaction and behavioural intention at holiday/vacation destinations, although tourist satisfaction has been variously defined. Nevertheless, there is general consensus that it is a post-consumption evaluative judgement (Westbrooke and Oliver, 1991; Yuksel and Yuksel, 2001). Indeed, a number of authors have described it as the 'outcome' for the tourist after the consumption of a tourism product or service (inter alia Crompton and Love, 1995; Baker and Crompton, 2000; Kozak, 2001a). Pizam et al. (1978), for example, measured tourist satisfaction with Cape Cod, MA, USA, using 32 destination characteristics. A factor-analytical approach produced eight dimensions, a mix of 'primary' and 'secondary' elements: 'beach opportunities', 'cost', 'hospitality', 'eating and drinking facilities', 'accommodation facilities', 'campground facilities', 'environment' and 'extent of commercialisation'. The authors stressed that their findings were not universally applicable because the nature of influencing factors depends on the destination area, its facilities, attractions and weather. Danaher and Arweiler's (1996) research on tourist satisfaction with vacations in New Zealand identified four components: 'transportation', 'accommodation', 'outdoor activities' and 'attractions'. Using multiple regression analysis, they found both primary and secondary elements - accommodation, outdoor activities and attractions - had a significant influence on overall satisfaction, although only outdoor activities significantly influenced the likelihood of recommending New Zealand for a vacation. Kozak and Rimmington (2000) also identified four, albeit different, factors relating to tourist satisfaction with off-season holidays
53

54

55

56

57

\section{8}

$$
60
$$

68

69 
in Mallorca: 'destination attractiveness', 'tourist attractions and facilities', 'availability of English language' and 'facilities and services'. Intention to return to Mallorca was also significantly influenced by primary and secondary elements - 'destination attractiveness' and 'facilities and services'. Kozak's (2001b) later study of tourist satisfaction with Mallorca and Turkey compared British and German tourist satisfaction levels. He found eight factors, although most are different from those identified by Pizam et al. (1978) and from those found in other studies; this supports the notion of uniqueness rather than universality of destination factors influencing satisfaction. The factors, a mix of 'secondary' and 'conditional' elements, explained $64 \%$ of the total variance in satisfaction. They were 'accommodation services', 'local transport services', 'hygiene and cleanliness', 'hospitality and customer care', 'facilities and activities', 'level of prices', 'language communication' and 'destination airport services'. Kozak also found that there was no consistency between the two nationalities in terms of their ratings on the variables which loaded on the factors. Huh and Uysal (2003) used principal components analysis to explore visitor perceptions of cultural/heritage in Virginia's Historic Triangle. They identified four factors, but they are different in character from those found by Danaher and Arweiler's (1996) and Kozak and Rimmington's (2000): 'general tour attraction', 'heritage attraction', 'maintenance factors' and 'cultural attraction'. Multiple regression analysis revealed that a primary element, 'heritage attraction', had the most influence on visitor satisfaction, although all four dimensions were significant. In their study of UK tourists' satisfaction with Orlando, Fallon and Schofield (2004) used factor analysis to explore underlying dimensions of satisfaction with the destination. The analysis produced a five-factor solution that explained $57 \%$ of the variance: 'facilitators', 'secondary attractions', 'tertiary attractions', 'core attractions' and 'transport plus'. The 'secondary attractions' were the single most influential factor affecting overall satisfaction followed by 'facilitators' and 'core attractions', but this varied depending on whether the tourists were first-time visitors or repeaters. Hasegawa (2010) used a Bayesian

Copyright (c) 2010 John Wiley \& Sons, Ltd. multivariate ordered probit model and Markov Chain Monte Carlo method, to analyse the satisfaction of tourists, who visited Hokkaido, Japan. The study assessed the relationship between overall satisfaction and satisfaction with a range of 'primary', 'secondary' and 'conditional' components of the visit. Satisfaction derived from the primary and secondary elements, 'scenery' and 'meals' respectively, was found to have the most influence on overall visitor satisfaction. These studies, in a range of different contexts, highlight the variability in the factors of significance associated with both the type of destination and the type of tourists.

\section{Tourist satisfaction in an urban context}

The factors which influence visitor satisfaction and behavioural intention in an urban context and at day-trip destinations have received far less attention. Bramwell's (1998) study of Sheffield's tourism product, measured visitor satisfaction with 15 elements of the city's tourism product. He identified six 'primary' elements, four 'secondary' elements and five 'conditional' elements. Visitors were most satisfied with the 'primary' attractions (the swimming complex, arena and the theatre) and the 'secondary' facilities (shopping). Schofield's (2001) study of visitor satisfaction with Castlefied Urban Heritage Park, Manchester, identified eleven dimensions of the 'product' from the visitor perspective, which explained $70 \%$ of the total variance. The components were 'extensive leisure provision and social opportunities', 'entertainment and conviviality', 'history and education', 'undemanding recreation', 'quality of the site', 'amusement and comfort', 'safety and security', 'wet weather facilities', 'special interests', 'peace and quiet' and 'good value'. The analysis demonstrated the complexity of the visitor experience of this day-trip destination and the important influence of not only 'primary' components, but also 'secondary' and 'conditional' components on visitor satisfaction. Baloglu et al. (2003) analysed the relationships among visitors' perceptions of destination performance and their overall satisfaction in Las Vegas. A factor analysis of the performance attributes produced three dimensions that explained $55 \%$ of the total

53

54

55

56

57

58

$$
60
$$

$$
61
$$$$
63
$$

\section{4}

$$
65
$$

67

\section{69}

\section{0}

84
85 
variance: 'variety of activities/entertainment', 'quality of product/environment' and 'value/ diversity'. Using multiple regression analysis, they found that the primary element, 'variety of activities/entertainment', had a significant positive impact on visitors' overall satisfaction. Again, the results show that both 'primary' and 'secondary' elements (and in one case, 'conditional' elements) influence the visitor experience of place and overall levels of visitor satisfaction and that their relative influence tends to vary with each destination.

The variation in factor significance across visitor types has also been found in an urban context. For example, many studies of day trips to cities have found that 'secondary' elements are a critical constituent of the visitor experience. These include shopping opportunities and the availability of places to eat and drink (Kent et al., 1983; Hudman and Hawkins, 1989; Chadee and Mattsson, 1996; Tribe and Snaith, 1998). Indeed, shopping is one of the most important activities for tourists (Moscardo, 2004; Kemperman et al., 2009) and is therefore an important destination attribute and motivational characteristic (Sirakaya et al., 2003). Similarly, the availability of restaurants and the quality of food at a destination can significantly influence day-trip decisions, although it is notable that shopping and dining can be both primary and secondary trip motivators (Quan and Wang, 2004).

These studies indicate that not only do the factors, which influence tourist satisfaction and/or behavioural intention, vary between destinations and their products, but that there is no universal formula for all tourists at any one destination. This supports the rationale for this study, which aimed to develop our understanding of the day-trip visitor experience and the factors underpinning their satisfaction with regenerated urban waterfront areas with particular reference to the Quays in the city of Salford.

\section{METHODOLOGY}

A mixed-method approach was employed for the primary research. This consisted of preliminary qualitative research, including 25 interviews with a purposive sample of day-trip visitors to the Quays and a content

Copyright (c) 2010 John Wiley \& Sons, Ltd. analysis of the destination's promotional material to determine the key components of the tourism product from a supply perspective. The qualitative data was then used to design a questionnaire that was used as the main instrument for the visitor survey, which was undertaken in August and September 2005.

\section{Instrumentation}

The questionnaire was designed to measure visitor perceptions of the Quays, their on-site behaviour, overall satisfaction with the visit and intention to both recommend and revisit the destination. The instrument was organized into sections relating to purpose of visit, frequency of previous visits, perception of the day-trip product and the overall outcome variables. It also included response sets to capture socio-demographic variables including group size and composition, age, occupation, education, gender, origin, purpose of visit and travel mode.

The principal construct in the questionnaire consisted of 30 destination attributes pertaining to the Quays presented on balanced fivepoint Likert-type scales. These were labelled as 'Disagree Strongly' (1), 'Disagree' (2), 'Neither Agree Nor Disagree' (3), 'Agree' (4) and 'Agree Strongly' (5), with an additional 'Do not know' option to distinguish the latter from the 'Neither Agree Nor Disagree' option. The attributes were gleaned from the pertinent literature (inter alia Discoll et al., 1994; Crompton and Love, 1995; Schofield, 2000; Joppe et al., 2001; Kozak, 2001b; Yuksel and Yuksel, 2001; Beerli and Martin, 2004; Hsu et al., 2004), from the front-end qualitative research with visitors to the Quays and from a content analysis of the promotional literature. Visitors' overall satisfaction with the Quays and their intention to return to the destination were also measured using five-point agreement/disagreement scales. The satisfaction scale options were: 'Very Dissatisfied' (1), 'Dissatisfied' (2), 'Neither Satisfied Nor Dissatisfied' (3), 'Satisfied' (4) and 'Very Satisfied' (5), and the options on the intention to return and recommend the destination were: 'Very Unlikely' (1), 'Unlikely' (2), 'Neither Likely Nor Unlikely' (3), 'Likely' (4) and 'Very Likely' (5).

Int. J. Tourism Res. (2010)

53

54

55

56

57

58

59

60

61

\section{2}

$$
84
$$

103
104 


\section{Sampling design}

After an initial pilot study, which resulted in minor amendments to the instrument, the data was gathered using an on-site self-administered questionnaire survey that was distributed around the Quays' attractions, bars, restaurants and distributional outlets. Additionally, using the same instrument, an on-site intercept survey was also carried out. Krejcie and Morgan's (1970) formula, as recommended by Jennings (2001), was used to calculate a viable sample for the survey. It was estimated that approximately two million people visited the Quays in 2003 (Salford City Council, personal communication, 2004), but no further breakdown of this figure was available on any aspect of the visitor profile. A minimum sample of 387 subjects was therefore required. De Vaus (2002) and Veal (2006) also suggest a sample size of 387 subjects for a population of two million with a $5 \%$ margin of error. A total of 392 useable questionnaires were obtained from a convenience sample of visitors. A non-probability sample was taken because of the constraints imposed by the destination's numerous entry and exit points, the dispersal of the visitors around the destination's attractions and amenities and the restricted opportunities for interception. However, the sample is considered to be representative of typical visitors to the Quays because the target population was sampled at nine different locations throughout the destination. The sample consists of 50.5\% males and is subdivided into the following age groups: $25.8 \%$ (16-24), 20.4\% (25-34), 18.9\% (35-44), $12.8 \%$ (45-54), 11.0\% (55-64) and $11.2 \%$ (65+). Visitor origin is subdivided into four categories: Salford (17.9\%), Greater Manchester $(31.9 \%)$, UK (48.4\%) and international (1.8\%).

\section{Data analysis}

The data were analysed using SPSS Version 16.0. Pearson product-moment correlation was used to assess the construct validity of the measurement scale (Yuksel and Rimmington, 1998). First, a 'perceived destination attribute index' was computed for the Quays - a composite index derived from the sum of the means of respondents' ratings on all 30 destination attributes (Ridgway et al., 2008). Coefficients were then computed for correlations between

Copyright (c) 2010 John Wiley \& Sons, Ltd. this index and the mean figures for subjects' ratings on the overall satisfaction, intention to recommend and intention to return scales. The results indicate that the 30 -item destination attribute construct has convergent and discriminant validity because the correlation with overall satisfaction (0.602) is higher than with intention to recommend (0.536) and intention to return (0.194) to the destination. The scale also has nomological validity because overall satisfaction correlates in a theoretically predicted way with intention to recommend and to return, i.e. visitors are more likely to recommend the destination to others than to return, and correlations are higher for intention to recommend (0.536) than for intention to return (0.194). Cronbach's alpha coefficient for the measurement scale was 0.93 , indicating a high degree of internal consistency. Exploratory factor analysis, using principle components as the method of extraction, was conducted on the visitor ratings on each of the 30 attributes to identify the perceived performance dimensions of the Quays. Least squares regression, using a forward stepwise entry, was employed to examine the influence of the factors on the overall outcome variables; a forward stepwise procedure was used because there were two or more statistically significant predictors (Field, 2009).

\section{RESEARCH FINDINGS}

Subjects' ratings on the destination attributes for the Quays are presented in Table 1. The five highest rated attribute statements are 'a clean environment' (4.10), 'interesting buildings' (4.09), 'an attractive place' (4.08), 'good car park facilities' (3.95) and 'good customer service' (3.80). Over $70 \%$ of subjects either agree or agree strongly about the first four (over $80 \%$ on the first three); this decreases to just under $65 \%$ on 'good customer service' (with 26.3\% in the neither agree nor disagree category). It should be noted that only 53.3\% thought that the Quays had 'good quality attractions'. It is also interesting that less than $50 \%$ of subjects either agree or agree strongly that the Quays has 'good wheelchair access' $(48.4 \%)$, 'good tourist information' (46.7\%) and is a 'historical place' $(49.0 \%)$. Moreover, less than $40 \%$ either agree or agree strongly about

53

54

55

56

57

58

60

\section{1}

$$
62
$$

64

\section{5}

\section{7}$$
69
$$

71

72
73
74

74

\section{76}

\section{7}

79

80
81

84
85 
Table 1. Quays' visitor ratings on the destination attributes

\begin{tabular}{|c|c|c|c|c|c|c|c|c|}
\hline Quays' attributes & Mean & SD & $\begin{array}{l}\text { Disagree } \\
\text { strongly } \\
(\%)\end{array}$ & $\begin{array}{c}\text { Disagree } \\
(\%)\end{array}$ & $\begin{array}{c}\text { Neither } \\
\text { agree nor } \\
\text { disagree }(\%)\end{array}$ & $\begin{array}{c}\text { Agree } \\
(\%)\end{array}$ & $\begin{array}{c}\text { Agree } \\
\text { strongly } \\
(\%)\end{array}$ & $\begin{array}{c}\text { Do not } \\
\text { know } \\
(\%)\end{array}$ \\
\hline A clean environment & 4.10 & 0.77 & 0.3 & 4.3 & 10.7 & 54.1 & 30.1 & 0.5 \\
\hline Interesting buildings & 4.09 & 0.78 & 0.8 & 3.6 & 11.2 & 54.3 & 29.1 & 1.0 \\
\hline An attractive place & 4.08 & 0.68 & 0.5 & 2.6 & 8.7 & 64.8 & 23.2 & 1.0 \\
\hline Good car park facilities & 3.95 & 0.86 & 1.5 & 4.6 & 13.8 & 49.5 & 23.2 & 7.4 \\
\hline Good customer service & 3.80 & 0.77 & 0.8 & 2.8 & 26.3 & 49.2 & 15.3 & 5.6 \\
\hline A relaxing place & 3.80 & 0.78 & 0.5 & 5.9 & 20.9 & 56.1 & 14.5 & 2.0 \\
\hline A friendly place & 3.79 & 0.71 & 0.5 & 2.8 & 26.0 & 56.4 & 12.5 & 1.8 \\
\hline A place to take the family & 3.78 & 0.86 & 1.3 & 8.4 & 16.1 & 56.6 & 15.3 & 2.3 \\
\hline It has educational value & 3.76 & 0.92 & 2.0 & 7.7 & 19.9 & 49.2 & 18. 4 & 2.8 \\
\hline Easy to get around & 3.75 & 0.94 & 2.0 & 10.7 & 14.5 & 54.6 & 17.6 & 0.5 \\
\hline Good wheelchair access & 3.74 & 0.80 & 1.0 & 2.0 & 25.3 & 36.2 & 12.2 & 0.3 \\
\hline Good value for money & 3.67 & 0.84 & 1.3 & 5.6 & 29.1 & 44.4 & 13.0 & 6.6 \\
\hline A safe place & 3.66 & 0.84 & 1.8 & 6.1 & 25.8 & 49.2 & 11.2 & 5.9 \\
\hline A unique place & 3.63 & 0.98 & 3.3 & 8.2 & 26.3 & 41.8 & 16.8 & 3.6 \\
\hline A place to explore & 3.56 & 0.94 & 2.6 & 10.5 & 28.6 & 44.1 & 13.3 & 1.0 \\
\hline Good quality attractions & 3.53 & 0.87 & 1.5 & 9.4 & 32.7 & 43.1 & 10.2 & 3.1 \\
\hline Good tourist information & 3.50 & 0.84 & 1.0 & 8.7 & 32.4 & 38.5 & 8.2 & 11.2 \\
\hline A variety of attractions & 3.49 & 0.91 & 1.8 & 14.3 & 23.7 & 48.7 & 8.4 & 3.1 \\
\hline A trendy place & 3.47 & 0.94 & 1.8 & 13.5 & 29.6 & 40.6 & 11.2 & 3.3 \\
\hline Good quality shopping & 3.47 & 1.02 & 4.6 & 12.0 & 24.5 & 42.1 & 12.0 & 4.8 \\
\hline Good signposting & 3.46 & 1.08 & 6.4 & 13.5 & 20.4 & 45.9 & 12.8 & 1.0 \\
\hline A historic place & 3.44 & 1.02 & 3.3 & 14.3 & 27.8 & 35.5 & 13.5 & 5.6 \\
\hline Easy to get to & 3.40 & 1.12 & 7.7 & 14.8 & 18.6 & 45.9 & 11.7 & 1.3 \\
\hline Good places to eat/drink & 3.39 & 0.99 & 3.8 & 16.3 & 23.5 & 44.1 & 8.7 & 3.6 \\
\hline Something for everyone & 3.35 & 1.01 & 1.8 & 23.2 & 21.2 & 41.8 & 9.7 & 2.3 \\
\hline A surprising place & 3.24 & 0.93 & 2.8 & 17.6 & 38.0 & 31.9 & 7.1 & 2.6 \\
\hline An exciting place & 3.20 & 0.96 & 3.1 & 20.4 & 36.7 & 30.6 & 7.7 & 1.5 \\
\hline A good place to socialize & 3.19 & 1.00 & 4.1 & 19.6 & 30.6 & 30.6 & 7.1 & 7.9 \\
\hline Usually something new & 3.12 & 0.95 & 2.8 & 22.7 & 31.1 & 28.6 & 5.1 & 9.7 \\
\hline Good place for a night out & 2.84 & 1.10 & 9.2 & 26.8 & 25.5 & 19.4 & 5.9 & 13.3 \\
\hline Overall satisfaction & 3.88 & 0.80 & 0.5 & 6.2 & 16.6 & 57.3 & 19.2 & 0.2 \\
\hline Intention to recommend & 3.98 & 0.93 & 2.3 & 6.5 & 10.9 & 51.2 & 28.8 & 0.3 \\
\hline Intention to revisit & 4.31 & 0.92 & 2.4 & 4.1 & 4.2 & 37.2 & 51.3 & 0.8 \\
\hline
\end{tabular}

the Quays being 'a surprising place' (39.0\%), 'an exciting place' (38.3\%), 'a good place to socialize' $(37.7 \%)$, about there 'usually being something to see' $(33.7 \%)$ and particularly about it being 'a good place for a night out' $(25.3 \%)$. The last (lowest rated) attribute is notable for the comparatively high levels of disagreement among visitors about this statement $(36.0 \%)$.

Overall, the majority of visitors feel positively predisposed towards the Quays and less than one-fifth disagree with positive statements about all but two of the destination's attributes. Moreover, the ratings for overall satisfaction show that the large majority $(76.5 \%)$ of subjects were either satisfied $(57.3 \%)$ or very satisfied (19.2\%) with their visit to the Quays. This is a positive outcome for the Quays because it is still developing as a visitor destination and has the potential to improve further in line with visitor needs and wants. Moreover, the large majority of subjects $(80.0 \%)$ were either likely $(51.2 \%)$ or very likely $(28.8 \%)$ to recommend the Quays to others and, significantly, 88.5\% indicated that they were either likely $(37.2 \%)$ or very likely $(51.3 \%)$ to return to the destination.$$
75
$$

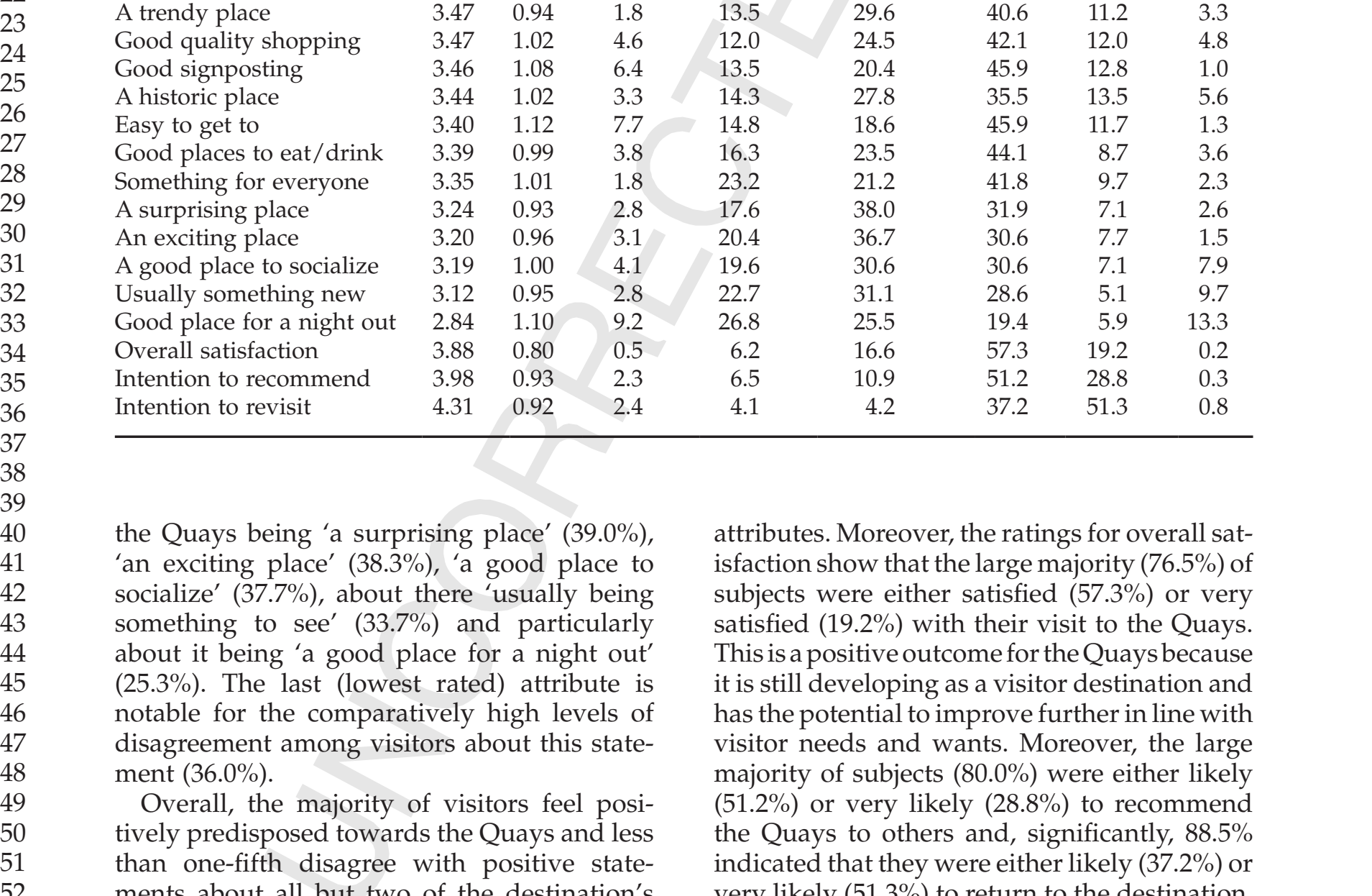

\footnotetext{
Copyright (C) 2010 John Wiley \& Sons, Ltd.
}

Int. J. Tourism Res. (2010) 
However, while the overall outcome is positive and the analysis of individual attributes has highlighted key strengths such as the clean environment, interesting architecture, good car parking facilities and the overall attractiveness of the destination, the low ratings for some variables should be noted. The destination is not perceived as being a surprising or exciting place and it is not considered to be a good place to socialize, particularly on a 'night out'. It is also interesting to note that when visitor ratings for overall satisfaction were regressed against the destination attributes, only 'a historical place' $(p=0.02)$, 'something for everyone' $(p=0.04)$, 'good quality shopping' $(p=0.008)$ and 'a unique place' ( $p=0.04)$ were significant predictors. Two variables: 'a clean environment' $(p=0.03)$ and 'good quality shopping' $(p=0.004)$ were significant for intention to recommend the destination and only 'a surprising place' ( $p=0.003$ ) was significant for intention to revisit the Quays.

Independent samples $t$-tests and one-way (between groups) analysis of variance showed that visitor ratings on the Quays' destination attributes were significantly differentiated on the basis of socio-demographic and behavioural characteristics (Table 2). Gender was not significant for $83.3 \%$ of the variables, although female ratings were significantly higher than males on five attributes: clean environment, attractiveness, customer service, friendliness and value for money. Age was significant for 13 of the variables $(43.3 \%)$ in which case, there was a statistically significant increase in agreement with visitor age. This was also the case for both visitors' level of education and social class, i.e. higher levels of agreement corresponded with higher levels of education (on $20 \%$ of variables) and social class (on $53.3 \%$ of variables). Visitor origin was significant for 12 $(40 \%)$ variables; there were significantly higher levels of agreement with the statements by visitors from the UK compared with both residents of Salford and Greater Manchester International visitors were excluded from the analysis because of the small sample. Significant differences were also found on the basis of subjects' reasons for visiting the Quays. It is interesting that the attribute ratings of subjects who were sightseeing, visiting an attraction or shopping were significantly higher than those who were employed on the Quays for the large majority of variables. Notably, the employed segment's ratings were significantly lower than the leisure visitor segment on $66.7 \%$ of the variables. For those who were visiting the Quays for a walk, ratings were significantly higher than other visitors on only one variable: 'good wheelchair access'.

The frequency of visits to the Quays was also found to be a significant variable; there was a decrease in visitor ratings on $18(60.0 \%)$ of the attributes with increasing frequency of visitation; this suggests a diminishing level of interest with an increasing number of visits. Visitor perceptions of the Quays were also influenced by the characteristics of the group who visited. Subjects who visited the Quays on their own, rated $11(36.7 \%)$ of the destination's performance attributes significantly lower than those who visited in groups of two or more people with the exception of those who visited with business colleagues; the latter rated 13 attributes $(43.3 \%)$ significantly lower than the equivalent leisure groups. Visits with a partner or with family produced significantly higher ratings on $10(33.3 \%)$ and $11(36.7 \%)$ attributes respectively. Visiting with friends did not seem to influence ratings with the exception of their higher level of agreement with 'good quality shopping'. Group size was also a significant influence on visitor ratings with respect to six attributes (20.0\%). In all cases except 'good quality shopping', levels of agreement increased significantly with increasing group size. For 'good quality shopping', there was a significant increase in agreement with increasing group sizes up to 10 and a significant decrease above 10 .

Overall, the socio-demographic and behavioural variables had the most significant influence on visitor levels of agreement with statements about 'good quality shopping', 'a clean environment', 'a good place for a night out', 'easy to get around', 'good signposting' and 'usually something new to do'. By comparison, there was minimal differentiation on visitor ratings on 'a place to take the family', 'good customer service', 'a relaxing place', 'good car park facilities', 'good tourist information' and 'a historical place'.

Visitor ratings on overall satisfaction, intention to recommend and intention to return to

53

54

55

56

58

61
62
63
Copyright 62010 J John Wiley \& Sons L Lt. 


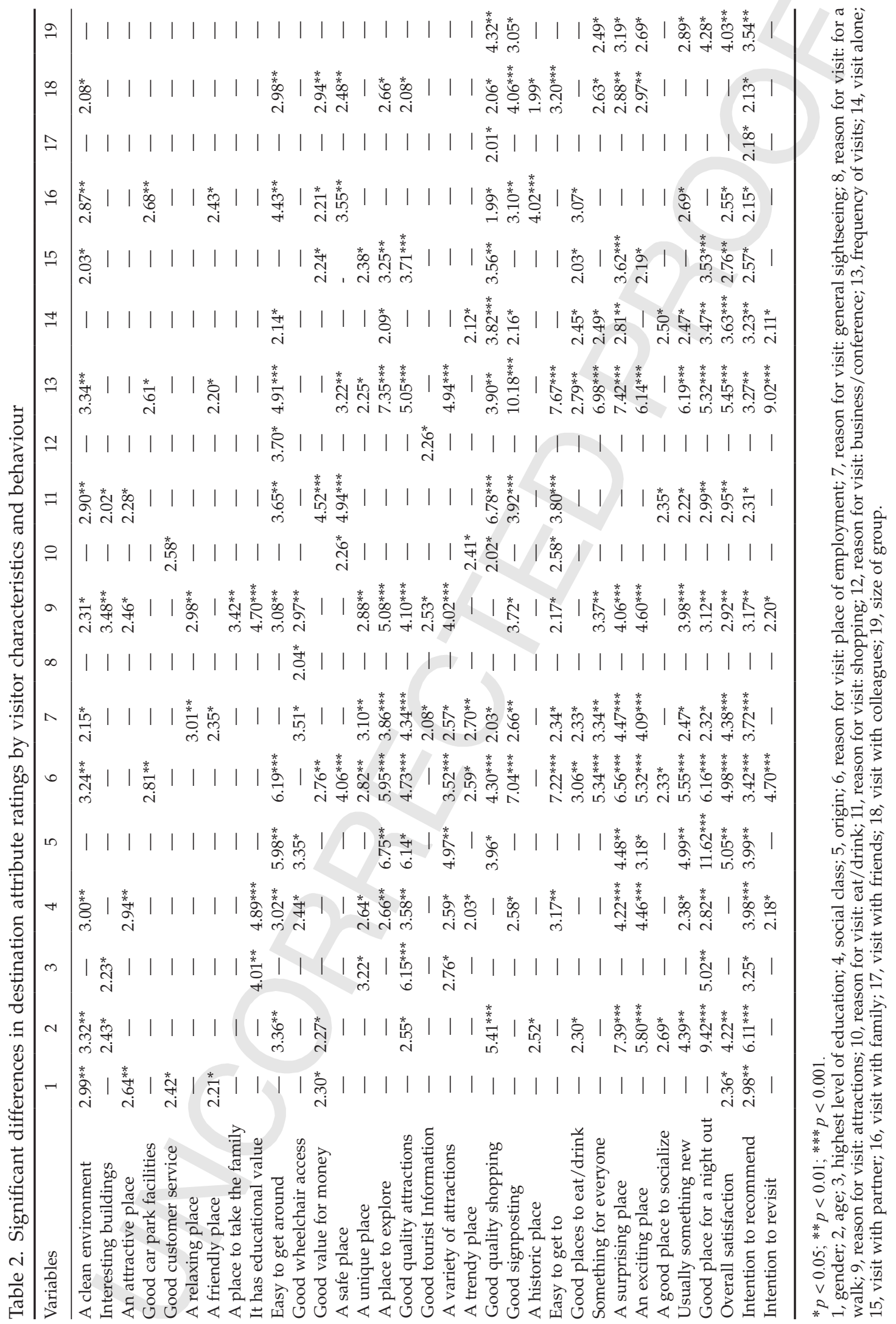

53

54

55

56

57

58

59

60

61

62

63

64

65

\section{6}

67

68

69

70

72

73

\section{4}

75
76

77
78

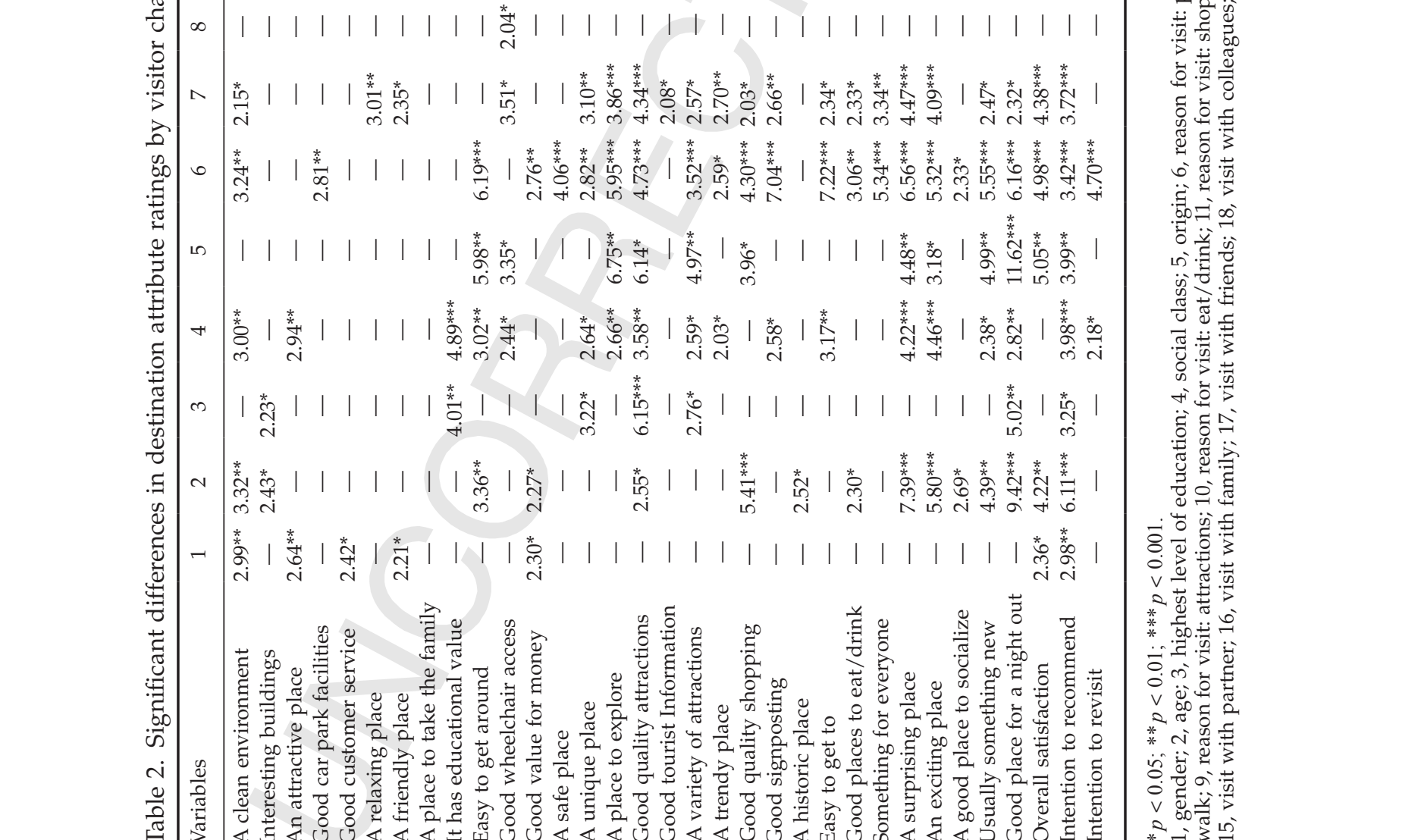


the Quays were also differentiated on the basis of the socio-demographic and behavioural variables. Overall satisfaction was differentiated on $12(63.2 \%)$ variables, intention to recommend on $16(84.2 \%)$ and intention to return on only five $(26.32 \%)$. The influence of the socio-demographic and behavioural variables was similar to that reported above for the ratings on the statements about the Quays with a few exceptions. On the overall satisfaction scale, there were significantly higher ratings for females, older age groups, subjects who were general sightseeing, visiting attractions and shopping. Satisfaction ratings also significantly increased with group size, distance travelled to the Quays and increasing frequency of visits up to three or four times per year (and decreased thereafter). Satisfaction ratings were significantly lower for those who visited alone and for those were employed on the Quays compared with the leisure visitor segment.

The influence of the socio-demographic and behavioural variables on visitor intention to recommend the Quays follows a similar pattern, including the more complex frequency of visits effect. In addition, visitor level of education, social class, distance travelled to the Quays and visiting with friends and colleagues have a significant positive effect on visitor intention to recommend. While the satisfaction ratings of those who visited the destination alone were significantly lower, they were significantly higher for intention to recommend. Visitor intention to revisit the Quays is not significantly differentiated with the exception of five variables. It is significantly higher for visitors in the higher social classes and, as would be expected, for subjects who are employed on the Quays. Notably, it is significantly lower for those visiting attractions although surprisingly, as was the case for intention to recommend the destination, it is significantly higher for those visiting on their own. It also increases significantly with increasing frequency of

\section{Perceived dimensions}

The results from the principal components analysis (PCA) of subjects' ratings on the destination attributes are presented in Table 3. Oblique rotation was used because the dimenvisitation. cal terms (Pedhazur and Schmelkin, 1991; Tabachnick and Fidell, 2007). Items were retained if they loaded 0.4 or higher on a factor as recommended by Stevens (1992) for the sample size, and if they did not load higher than 0.4 on two or more factors. All but one of the items loaded on the factors at 0.67 or above indicating a good correlation with the factor groups they belong to. All factors with eigenvalues greater than or equal to one and a reliability coefficient above 6.0 were retained (Churchill, 1979). Fifteen items were removed from the PCA because they loaded on two or more dimensions; this is a significant reduction, which indicates that many of the variables are interrelated. The remaining fifteen items produced a four-factor solution that explained $63.5 \%$ of variance in the data before rotation.

Factor $1(\alpha=0.85)$ accounts for $35.82 \%$ of the variance in the data and the attribute loadings suggest that it relates to either the primary attractions or primary motivations for visiting the Quays and was labelled primary attractions. Factor $2(\alpha=0.79)$ explains $11.76 \%$ of the variance and seems to describe the 'secondary elements of place' (Jansen-Verbeke, 1986). Factor $3(\alpha=0.74)$ accounts for $8.43 \%$ of the variance and was labelled access because it loads on attributes relating to signposting and movement both to and around the Quays. Factor 4 ( $\alpha=0.61$ ) accounts for $7.49 \%$ of the variance and loads on attributes relating to the environment. There appears to be a good fit between the four-factor solution and Jansen-Verbeke's (1986) leisure function of the inner city in that 'primary', 'secondary' and 'conditional' elements are identified. The outcome also has similarities with Fallon and Schofield's (2004) five-factor solution that identified core attractions, secondary attractions and transport plus factors, albeit in two different types of destination.

There were significant differences on the four dimensions with respect to the large majority of the visitor socio-demographic and behavioural characteristics (Table 4). Overall, it is interesting that while the first three dimensions are differentiated on between one-third and two-thirds of the variables, the environment dimension is undifferentiated. This sions were considered to be related in theoreti-

53

54

55

56

58

$$
\begin{aligned}
& 59 \\
& 60
\end{aligned}
$$

60

68
69

\section{0}


Table 3. Perceived dimensions of the destination from the visitor perspective

\begin{tabular}{|c|c|c|c|c|c|}
\hline The Quays' attributes & Factor 1 & Factor 2 & Factor 3 & Factor 4 & Communality \\
\hline Factor 1: Primary attractions & - & - & - & - & - \\
\hline A place to explore & 0.784 & - & - & - & 0.696 \\
\hline Good quality attractions & 0.734 & - & - & - & 0.633 \\
\hline A surprising place & 0.730 & - & - & - & 0.641 \\
\hline It has educational value & 0.700 & - & - & - & 0.494 \\
\hline An exciting place & 0.668 & - & - & - & 0.650 \\
\hline A trendy place & 0.556 & - & - & - & 0.506 \\
\hline Factor 2: Secondary elements & - & - & - & - & - \\
\hline Good places to eat/drink & - & 0.784 & - & - & 0.643 \\
\hline A good place to socialize & - & 0.767 & - & - & 0.667 \\
\hline Good quality shopping & - & 0.697 & - & - & 0.569 \\
\hline A good place for a night out & - & 0.674 & - & - & 0.592 \\
\hline Factor 3: Access & - & - & - & - & - \\
\hline Good signposting & - & - & 0.832 & - & 0.707 \\
\hline Easy to get around & - & - & 0.783 & - & 0.665 \\
\hline Easy to get to & - & - & 0.755 & - & 0.630 \\
\hline Factor 4: Environment & - & - & - & - & - \\
\hline A clean environment & - & - & - & 0.807 & 0.731 \\
\hline An attractive place & - & - & - & 0.789 & 0.702 \\
\hline Eigenvalue & 5.372 & 1.764 & 1.265 & 1.123 & - \\
\hline Variance $(\%)$ & 35.816 & 11.759 & 8.433 & 7.489 & - \\
\hline Cumulative variance (\%) & 35.816 & 47.575 & 56.008 & 63.497 & - \\
\hline Cronbach's alpha & 0.85 & 0.79 & 0.74 & 0.61 & - \\
\hline Number of items $($ total $=16)$ & 6 & 4 & 3 & 2 & - \\
\hline
\end{tabular}

KMO measure of sampling adequacy: 0.88 .

Barlett sphericity test statistic: 1786.62 ; degree of freedom: $120 ; p<0.001$ ).

results from the very high levels of agreement among visitors about the Quays being 'a clean environment' and 'an attractive place' (ranked first and third overall), which load on this dimension; a total of $84.2 \%$ and $88 \%$ of subjects either 'agree' or 'agree strongly' with the statements respectively. It should be noted that the primary attraction dimension is also undifferentiated on the basis of visitor gender and age, but differentiated on the basis of education level, social class, origin, reasons for a visit (employment, general sightseeing, attractions) and frequency of visits. The secondary elements dimension is differentiated on the basis of age, but also on the basis of origin, reason for a visit (employment, shopping), group characteristics (visiting alone, visiting with a partner) and group size. By comparison, the significant differentiating variables for the access dimension are gender, social class, origin, reason for a visit (employment, general sightseeing, attractions, eating and drinking, shopping), frequency of visits and group characteristics (visiting with a family, visiting with friends, visiting with colleagues).

\section{Predicting visitor satisfaction and intention to recommend and revisit the quays}

The results from the least squares regression analysis relating to the prediction of visitor satisfaction and intention to both recommend the Quays to others and revisit the destination are given in Table 5. The three models achieve satisfactory levels of goodness of fit in predicting their respective outcome variables. The 'visitor satisfaction' regression model is significant $(p<0.001)$ with all four dimensions making a contribution to visitor satisfaction. The $R^{2}$ value shows that the four-factor model explains
74

75

77 


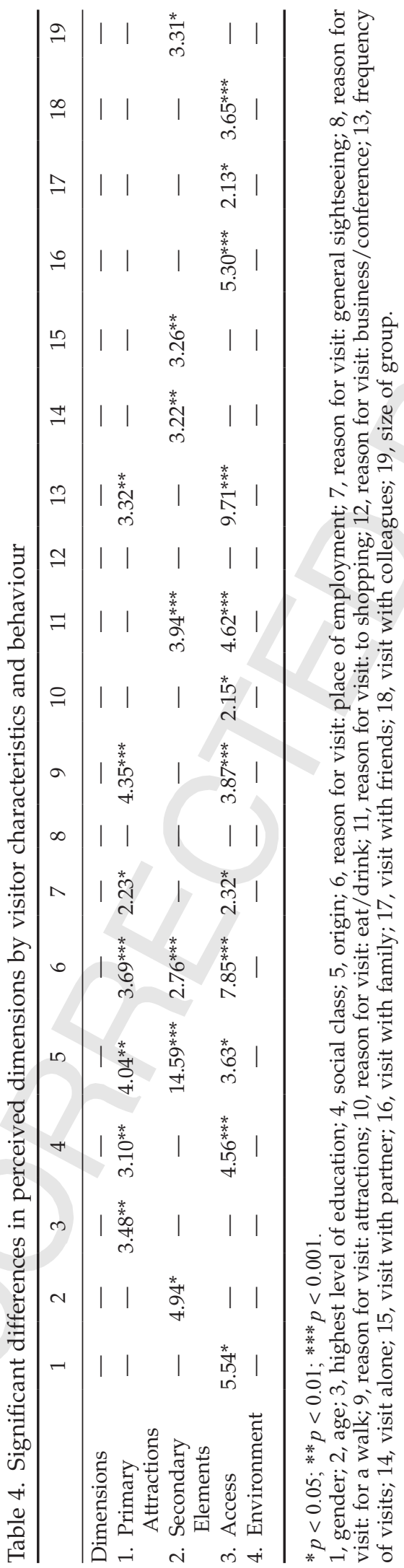

53

\begin{abstract}
2
\end{abstract}

$$
3
$$


Table 5. Regression of overall satisfaction, intention to recommend and intention to revisit the Quays on the four dimensions

\begin{tabular}{lcccccrr}
\hline A. Overall satisfaction with the Quays & \multicolumn{1}{l}{} \\
\hline Dimensions & B & SE B & Standard beta & T & Sig. & Tolerance & VIF \\
Factor 2: Secondary elements & 0.290 & 0.036 & 0.370 & 8.150 & $<0.001$ & 0.91 & 1.10 \\
Factor 1: Primary attractions & 0.284 & 0.036 & 0.360 & 7.920 & $<0.001$ & 0.91 & 1.10 \\
Factor 4: Environment & 0.194 & 0.035 & 0.250 & 5.503 & $<0.001$ & 0.92 & 1.09 \\
Factor 3: Access & 0.160 & 0.043 & 0.202 & 4.452 & $<0.001$ & 0.95 & 1.05
\end{tabular}

Multiple $R=0.611 ; R^{2}=0.373$; Adjusted $R^{2}=0.364$; Standard error $(\mathrm{SE})=1.09 ; F=45.16 ; p<0.001$

B. Intention to recommend the Quays

$\begin{array}{lccccccr}\text { Dimensions } & \mathrm{B} & \text { SE B } & \text { Standard beta } & \mathrm{T} & \text { Sig. } & \text { Tolerance } & \text { VIF } \\ \text { Factor 4: Environment } & 0.312 & 0.042 & 0.345 & 7.378 & <0.001 & 0.80 & 1.25 \\ \text { Factor1: Primary attractions } & 0.313 & 0.043 & 0.341 & 7.273 & <0.001 & 0.80 & 1.25 \\ \text { Factor 2: Secondary elements } & 0.289 & 0.043 & 0.316 & 6.748 & <0.001 & 0.74 & 1.35 \\ \text { Multiple } R=0.575 ; R^{2}=0.331 ; \text { Adjusted } R^{2}=0.325 ; \mathrm{SE}=1.11 ; F=50.35 ; p<0.001 & \end{array}$

C. Intention to revisit the Quays

Dimensions

Factor 2: Secondary elements

$\begin{array}{cc}\text { B } & S E \text { B } \\ 0.158 & 0.050 \\ 0.128 & 0.050 \\ 0.121 & 0.049\end{array}$

$\begin{array}{ccc}\text { Standard beta } & \text { T } & \text { Sig. } \\ 0.174 & 3.64 & 0.002 \\ 0.141 & 2.56 & 0.011 \\ 0.135 & 2.45 & 0.015\end{array}$

$\begin{array}{cc}\text { Tolerance } & \text { VIF } \\ 0.63 & 1.59 \\ 0.63 & 1.59 \\ 0.63 & 1.59\end{array}$

Factor 4: Environment

$0.121-0.049$

$0.135 \quad 2.45 \quad 0.015$

0.63

1.59

Multiple $R=0.260 ; R^{2}=0.068$; Adjusted $R^{2}=0.059 ; \mathrm{SE}=1.36 ; F=7.44 ; p<0.001$

The $95 \%$ confidence intervals for exp. $B=0.78-0.95$; Durbin-Watson statistics: $1.99 ; 1.98 ; 1.86$; the predictor variable 20 loadings on the dimensions in each regression model also indicate the absence of multicolinearity in the data.

$37.3 \%$ of the variance in overall visitor satisfaction. It is interesting to note that Factor 2 (secondary elements), makes the strongest contribution to overall satisfaction (0.370) when the variance explained by all other factors in the model is controlled for. However, Factor 1 (primary attractions) makes a similar contribution to the model (0.360).

The results show that secondary elements are as important as primary attractions in influencing visitor satisfaction at the Quays. This outcome lends support to the findings of Fallon and Schofield (2004) and Hasegawa (2010), who found secondary attractions to have a significant influence on overall tourist satisfaction at a number of different destinations. However, it should be noted that the variables, which load on the 'secondary elements' dimension, could represent important attractions, i.e. primary elements at the destination from the perspective of certain visitors. Eating/drinking and shopping opportunities have been found to function as attractions and play an important part in day trips to urban areas (Kent et al., 1983; Hudman and Hawkins, 1989; Sirakaya et al., 2003; Moscardo, 2004; Quan and Wang, 2004; Kemperman et al., 2009). It should also be noted that subjects were not 'highly' satisfied with the performance of the attributes loading on the secondary attractions factor. For example, 'good quality shopping' $($ mean $=3.47)$ and 'good places to eat/drink' (mean $=3.39)$. Additionally, the Quays is not perceived as 'a good place for a night out' (mean $=2.84)$ or 'a good place to socialize' (mean $=3.19)$. This indicates that although the destination's secondary elements are an important motivating factor, there is room for improvement to achieve higher levels of visitor satisfaction.

The importance of secondary elements notwithstanding, the emergence of primary attractions (Factor 1) as a significant predictor of visitor satisfaction supports both Baloglu et al.'s (2003) study and Huh and Uysal's (2003) research, which found the primary elements of 
place to be the key determinant of visitor satisfaction. The significance of both primary and secondary elements in the case of the Quays in Salford supports Danaher and Arweiler's (1996) research in particular; they found that both primary and secondary attractions had a significant impact on overall satisfaction.

Factor 4 (environment) and Factor 3 (access) make weaker, albeit significant, contributions to overall visitor satisfaction with the destination with figures of 0.250 and 0.202 respectively. The two variables loading on Factor 4 ('a clean environment' and 'an attractive place') were among the highest rated performance statements. This also supports Hasegawa's (2010) study because it also found an environmental dimension: 'satisfaction from scenic beauty', which had a significant influence on overall satisfaction. Given the importance of these environmental variables in relation to visitor satisfaction, these destination elements should also be given due consideration.

The results from the 'intention to recommend the Quays to others' regression model show that only three of the four dimensions make a significant contribution to the model $(p$ $<0.001$ ); they explain $33.1 \%$ of the variance in the outcome variable; the beta scores for the significant factors are also of the same order of magnitude as those predicting visitor satisfaction. It is interesting that the environmental dimension (Factor 4) makes the strongest contribution to subjects' intention to recommend the Quays to others (0.345), albeit a similar one to both that of the primary attractions (Factor 1) at 0.341 and secondary elements (Factor 2) at 0.316 . Moreover, the influence of the environment is stronger on subjects' intention to recommend than on visitor satisfaction. By comparison, it is notable that Factor 3 (access), the 'conditional' component of the product is not a significant predictor of subjects' intention to recommend the Quays.

The results from the intention to return to the Quays' regression model show that Factors 1,2 and 4 are also significant predictors of this outcome variable $(p<0.001)$, but as would be expected, explain less of the variance $(6.8 \%)$ compared with both visitor satisfaction (37.3\%) and intention to recommend the Quays to others $(33.1 \%)$. The relative importance of the dimensions reflects their rank order for pre- dicting visitor satisfaction; Factor 2 (secondary elements) makes the strongest contribution (0.17) followed by Factor 1 (primary attractions) with 0.140 and Factor 4 (environment) with 0.135 . As is the case with subjects' intention to recommend the Quays to others, Factor 3 (access) is not a significant predictor of subjects' intention to return to the destination. This suggests that overall, the access factor and its attendant variables, 'easy to get to', 'signposting' and 'easy to get around', are perceived as more basic requirements. The importance of the primary and secondary elements in influencing tourist intention to return to the destination also supports Kozak and Rimmington's (2000) findings.

\section{CONCLUSIONS AND RECOMMENDATIONS}

There is now an extensive literature on urban regeneration, but visitor perceptions and experiences of urban waterfront destinations have been neglected. This study has examined daytrip visitor perceptions of the Quays in Salford, the city's flagship tourism product, with a particular focus on the relative significance of the destination's primary, secondary and conditional dimensions on visitor satisfaction and intention to both recommend and revisit the Quays. As such, it addresses a gap in our knowledge and makes a theoretical contribution to the literature. The findings also have important practical implications for destination management.

There is a high level of visitor satisfaction with the Quays and the large majority of visitors were either likely or very likely to both recommend it to others and return in the near future. The secondary elements, primary attractions and the environment were key influences on overall visitor satisfaction and their intention to recommend and revisit. An important finding was that the secondary elements explained slightly more of the variance in overall satisfaction with the Quays and intention to revisit the destination than the primary attractions. Nevertheless, the primary attractions dimension was a significant predictor of all three outcome variables and the classification of certain elements of the tourism product as secondary may underplay their role
53

54

55

56

$$
59
$$

$$
61
$$

\section{7}

\section{9}

70 
in both motivating and enhancing the visitor experience. Overall, it is the combined effect of the secondary elements and primary attractions that explain most of the variance in the outcome variables; both dimensions also make significant contributions to subjects' intention to recommend the Quays to others, although the environment factor explains more of this particular behavioural outcome. Indeed, the environmental dimension has a significant influence on all three outcome variables, which highlights the contribution of a range of factors to visitor satisfaction and behavioural intention.

The prominence of the environment and primary attractions in explaining visitor intention to recommend the destination is particularly interesting given the importance of secondary elements in relation to the other outcome variables. This indicates that visitors do not recommend the destination on the basis of its secondary elements; instead, they refer to the general environment of the destination and its primary attractions, possibly for the sake of their credibility. Indeed, visitors were probably attracted themselves by the destination's main attractions as featured in the tourist promotional literature and/or in earlier word-ofmouth recommendations from others, notwithstanding the importance of the environment. However, the results show that overall, the secondary elements such as shops, cafes and restaurants together with the environmental features such as the overall cleanliness and attractiveness of the place are also key components of the product in terms of their contribution to overall satisfaction and intention to revisit the destination. By comparison, while the 'conditional' component of the product represented by the 'access' factor was a significant, albeit relatively weak predictor of overall satisfaction, it was not a significant predictor of subjects' intention to either recommend the Quays or return to the destination.

Previous research has acknowledged the importance of secondary elements of place in determining visitor satisfaction, but the majority of studies have focused on holiday/vacation destinations. The outcomes of this study, based on a day-trip product at an urban waterfront destination in the UK, suggest that a general model may exist, i.e. that secondary elements are as important as primary attractions for certain tourism product types in terms of satisfaction and intention to return to the place. However, even where the relative influence of the destination dimensions has been found to be similar in previous studies, there are often considerable differences between the 'same' dimensions (such as 'secondary elements') in terms of the individual attributes which load on them. Additionally, perceptions of destination variables and dimensions vary by segment even at the same destination. This indicates that while the elements of the 'leisure product' are common among different types of destination, their relative importance varies depending on the classification of product elements as either primary, secondary or conditional, the type of destination and/or the way it is perceived and experienced by different types of visitor. This supports the notion of destination dimension uniqueness rather than universality in terms of both the characteristics of dimensions and their role in visitor satisfaction and behavioural intention.

Overall, the findings of the research provide valuable information for Salford City Council in relation to planning and marketing the Quays with particular reference to product development and promotional strategies. The analysis of the visitor perceptions of the product attributes has highlighted key strengths such as the clean environment, interesting architecture, good car parking facilities and the overall attractiveness of the destination. However, the low ratings for some variables indicate that, from a management perspective, they should be targeted for improvement, particularly where they have a significant influence on visitor satisfaction. For example, just under half of the people surveyed thought that the attractions were not of good quality, that the destination was not a surprising or exciting place and not a good place to socialize, particularly at night.

A further but significant finding was the variation in perceptions of the Quays on the basis of visitor socio-demographics and behaviour. Many of the destination attributes were more appealing to older age groups, higher social class groups, visitors with higher levels of education, visitors from outside Greater Manchester, those who were sightseeing,
53

54

55

56

57

\section{8}

\section{1}$$
63
$$

\section{4}

66
67

68

\section{0}

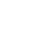

74

77


visiting an attraction or shopping and those who visited the destination either with their partner or with their family. There was also a significant increase in the appeal of one-fifth of the destination's attributes as group size increased, indicating a positive group effect, and a significant decrease in the appeal of twothirds of the destination's attributes as the frequency of visits to the Quays increased, which suggests that product augmentation should be considered to address the diminishing returns with increasing visitation. Visitor perceptions about the quality of shopping, the night-time attractions, the cleanliness of the environment, access, signposting and whether or not there was usually something new to do at the destination were the most significantly differentiated variables on the basis of visitor socio-demographics and behavioural traits. Moreover, the significantly higher overall satisfaction ratings for females, older age groups, larger group sizes, visitors from outside Greater Manchester and subjects who were sightseeing, visiting attractions and shopping also highlight important segmentation and targeting opportunities. The synergy from the combined effect of the destination's primary, secondary and conditional elements should also be acknowledged and effectively managed. Given the importance of secondary elements and the fact that subjects were not 'highly' satisfied with the attributes that load on this dimension, improvements in this area should be prioritized. Additionally, the results also indicate that the destination's promotional material should place further emphasis on its secondary elements. At present, the Quays' primary attractions are featured most prominently.

This research represents a cross-sectional study of day-trip visitors at one urban waterfront destination in the UK. Further research is therefore needed to assess visitor perceptions, behaviour and experience in other locations; this would allow meaningful comparisons to be made and the uniqueness of destination dimensions to be assessed. Finally, while the management implications of this study are limited to the Quays, the research methodology could be applied at other destinations to examine visitor perceptions of product attributes and dimensions, and evaluate their influ- ence on visitor satisfaction and behavioural intention to assess the general applicability of the findings.

\section{REFERENCES}

Ashworth G, Page S. 2010. Urban tourism research: recent progress and current paradoxes. Tourism Management 1-15 (in press).

Baker DA, Crompton JL. 2000. Quality, satisfaction and behavioural intentions. Annals of Tourism Research 27(3): 785-804.

Baker M, Page S. 2002. Visitor safety in urban tourism environments: the case of Auckland, New Zealand. Cities 19(4): 273-282.

Baloglu S, Pekan A, Chen S, Santos J. 2003. The relationship between destination performance, overall satisfaction and behavioural intention for distinct segments. In Current Issues and Development in Hospitality and Tourism Satisfaction, Williams JA, Uysal M (eds). The Haworth Hospitality Press: New York; 149-176.

Beerli A, Martin JD. 2004. Tourists' characteristics and the perceived image of tourist destinations: a quantitative analysis. Tourism Management 25(5): 623-636.

Bramwell B. 1998. User satisfaction and product development in urban tourism. Tourism Management 19(1): 35-47.

Chadee DD, Mattsson J. 1996. An empirical assessment of customer satisfaction in tourism. Services Industries Journal 16(3): 305-320.

Churchill GA. 1979. A paradigm for developing better measures of marketing constructs. Journal of Marketing Research 16(1): 64-73.

Craggs R, Schofield P. 2009. Expenditure-based segmentation and visitor profiling at the Quays in Salford. Tourism Economics 15(2): 243-260.

Craig-Smith SJ. 1995. The role of tourism in inner-harbour redevelopment. In Recreation and Tourism as a Catalyst for Urban Waterfront Redevelopment: An International Survey, Craig-Smith SJ, Fagence M (eds). Praeger Publishers: Westport, CT; 15-35.

Crompton JL, Love LL. 1995. The predictive validity of alternative approaches to evaluating quality of a festival. Journal of Travel Research 34(1): 11-24.

Danaher PJ, Arweiler N. 1996. Customer satisfaction in the tourist industry: a case study of visitors to New Zealand. Journal of Travel Research 35(1): 89-93.

De Vaus DA. 2002. Surveys in Social Research. 4th edn. UCL Press: London.

Discoll A, Lawson R, Niven B. 1994. Measuring tourists' destination perceptions. Annals of Tourism Research 21(3): 499-511. 
Fallon P, Schofield P. 2004. 'First-time versus repeat visitor satisfaction: the case of Orlando, Florida'. Tourism Analysis 8(2/4): 205-210.

Field A. (2009). Discovering Statistics Using SPSS. 3rd edn. Sage: London.

Hasegawa H. 2010. Analyzing tourists' satisfaction: a multivariate ordered probit approach. Tourism Management 31(1): 86-97.

Hsu CHC, Wolfe K, Kang SK. 2004. Image assessment for a destination with limited comparative advantages. Tourism Management 25: 121-126.

Hudman LE, Hawkins DE. 1989. Tourism in Contemporary Society. Prentice Hall: Englewood Cliffs, NJ.

Huh J, Uysal M. 2003. Satisfaction with cultural/ heritage sites: Virginia historic triangle. Journal of Quality Assurance in Hospitality and Tourism 4(3/4): 177-194.

Jansen-Verbeke M. 1986. Inner-city tourism: resources, tourists and promoters. Annals of Tourism Research 13: 79-100.

Jennings G. 2001. Tourism Research. Wiley: Milton, Queensland.

Joppe M, Martin DW, Waalen J. 2001. Toronto's image as a destination: a comparative importance-satisfaction analysis by origin of visitor. Journal of Travel Research 39: 252-260.

Kaiser HF. 1974. An index of factorial simplicity. Psychometrika 39(1): 31-36.

Kemperman AD, Borgers AW, Timmermans HJ. 2009. Tourist shopping behaviour in a downtown historic area. Tourism Management 30(2): 208-218.

Kent WE, Shock J, Snow RE. 1983. Shopping: tourism's unsung hero(ine). Journal of Travel Research 21(4): 2-4.

Kozak M. 2001a. A critical review of approaches to measure satisfaction with tourist destinations. In Consumer Psychology of Tourism, Hospitality and Leisure, Vol. 2, Mazanec JA, Crouch GI, Brent Ritchie JR, Woodside AG (eds). CABI Publishing: Oxon, UK; 303-318.

Kozak M. 2001b. Comparative assessment of tourist satisfaction with destinations across two nationalities. Tourism Management 22: 391-401.

Kozak M, Rimmington M. 2000. Tourist satisfaction with Mallorca, Spain, as an off-season holiday destination. Journal of Travel Research 38: 260-269.

Krejcie RV, Morgan DW. 1970. Determining sample size for research activities. Educational and Psychological Measurement 30: 607-610.

Moscardo G. 2004. Shopping as a destination attraction: an empirical examination of the role of shopping in tourists' destination choice and experience. Journal of Vacation Marketing 10(4): 294-307.

Copyright $(92010$ John Wiley \& Sons, Ltd.
Page S, Hall M. 2002. Managing Urban Tourism. Prentice Hall: Harlow, UK.

Pearce DG. 2001. An integrative framework for urban tourism research. Annals of Tourism Research 28(4): 926-946.

Pedhazur E, Schmelkin L. 1991. Measurement, Design and Analysis. Erlbaum: Hillsdale, NJ.

Pizam A, Neumann Y, Reichel A. 1978. Dimensions of tourist satisfaction with a destination area. Annals of Tourism Research 5(3): 314-322.

Quan S, Wang N. 2004. Towards a structural model of the tourist experience: an illustration from food experiences in tourism. Tourism Management 25(3): 297-305.

Ridgway NM, Kukar-Kinney M, Monroe KB. 2008. An expanded conceptualisation and a new measure of compulsive buying. Journal of Consumer Research 35(4): 622-639.

Schofield P. 2000. Deciphering day-trip destination choice using a tourist expectation/satisfaction construct. In Consumer Psychology of Tourism, Hospitality and Leisure, Woodside AG, Crouch GI, Mazanec JA, Oppermann M, Sakai MY (eds). CAB International: Oxon; 269-293.

Schofield P. 2001. Evaluating heritage visitor attractions from the consumer perspective: a focus on Castlefield Urban Heritage Park in Manchester, UK. In Consumer Psychology of Tourism, Hospitality and Leisure, Vol. 2, Mazanec JA, Crouch GI, Brent Ritchie JR, Woodside AG (eds). CABI Publishing: Oxon; 285-301.

Selby M. 2004. Understanding Urban Tourism: Image, Culture and Experience. I.B. Tauris: London.

Shaw G, Williams AM. 1994. Critical Issues in Tourism: A Geographical Perspective. Blackwell: Oxford.

Sirakaya E, Uysal M, Yoshioka CF. 2003. Segmenting the Japanese tour market to Turkey. Journal of Travel Research 41(3): 293-304.

Stevens J. 1992. Applied Multivariate Statistics for the Social Sciences. 2nd edn. Lawrence Erlbaum Associates: $\square$, NJ.

Struthers T. 2003. The Redevelopment of Salford Quays, Greater Manchester: Its Impact on Urban and Regional Development from 1983 to 2003. Salford City Council: Salford, UK.

Tabachnick BG, Fidell LS. 2007. Using Multivariate Statistics. 5th edn. Pearson: Boston.

Tribe J, Snaith T. 1998. From SERVQUAL to HOLSAT: holiday satisfaction in Varadero, Cuba. Tourism Management 19(1): 25-34.

Tyler A. 2000. A framework for analysing urban tourism. In Developments in Urban and Rural Tourism: Reflections on International Tourism, Robinson M, Sharpley R, Evans N, Long P, Swarbrooke J (eds). Business Education Publishers: Sunderland, UK; 287-299.
53

54

55

56

57

59

60

61

62

63

64 
Van der Knaap GA, Pinder DA. 1992. Revitalising the European waterfront: policy evolution and planning issues. In European Port Cities in Transition, Hoyle BS, Pinder DA (eds). Belhaven: London; 155-175.

Veal AJ. 2006. Research Methods for Leisure and Tourism: A Practical Guide. Pitman: London.

Westbrooke RA, Oliver RL. 1991. The dimensionality of consumption emotion patterns and con- sumer satisfaction. Journal of Consumer Research 18: 84-91.

Yuksel A, Rimmington M. 1998. Customer satisfaction measurement. Cornell Hotel and Restaurant Administration Quarterly $\square$ : 60-70.

Yuksel A, Yuksel F. 2001. Comparative performance analysis: tourists' perceptions of Turkey relative to other tourist destinations. Journal of Vacation Marketing 7(4): 333-355. 


\section{AUTHOR QUERY-FORM}

\section{Dear Author,}

During the preparation of your manuscript for publication, the questions listed below have arisen. Please attend to these matters and return this form with your proof.

Many thanks for your assistance.

\begin{tabular}{|c|c|c|}
\hline $\begin{array}{l}\text { Query } \\
\text { References }\end{array}$ & Query & Remarks \\
\hline 1. & $\begin{array}{l}\text { AUTHOR: Please confirm that the authors and the affiliation addresses are } \\
\text { correct. }\end{array}$ & \\
\hline 2. & $\begin{array}{l}\text { AUTHOR: van der Knaap and Pinder, } 1992 \text { has been changed to Van der } \\
\text { Knaap and Pinder, } 1992 \text { so that this citation matches the Reference List. } \\
\text { Please confirm that this is correct. }\end{array}$ & \\
\hline 3. & $\begin{array}{l}\text { AUTHOR: Barker and Page, } 2002 \text { has been changed to Baker and Page, } 2002 \\
\text { so that this citation matches the Reference List. Please confirm that this is } \\
\text { correct. }\end{array}$ & \\
\hline 4. & $\begin{array}{l}\text { AUTHOR: MediaCity:UK has been changed to MediaCityUK as per Internet } \\
\text { search. Please confirm if this is correct. }\end{array}$ & \\
\hline 5. & $\begin{array}{l}\text { AUTHOR: References Salford City Council } 2004 \text { and } 2009 \text { have been deleted } \\
\text { in the reference list as per journal requirement. Please confirm that this is } \\
\text { correct. }\end{array}$ & \\
\hline 6. & $\begin{array}{l}\text { AUTHOR: Westbrook and Oliver, } 1991 \text { has been changed to Westbrooke and } \\
\text { Oliver, } 1991 \text { so that this citation matches the Reference List. Please confirm } \\
\text { that this is correct. }\end{array}$ & \\
\hline 7. & $\begin{array}{l}\text { AUTHOR: Chadee and Mattson, } 1996 \text { has been changed to Chadee and } \\
\text { Mattsson, } 1996 \text { so that this citation matches the Reference List. Please } \\
\text { confirm that this is correct. }\end{array}$ & \\
\hline 8. & $\begin{array}{l}\text { AUTHOR: Driscoll et al., } 1994 \text { has been changed to Discoll et al., } 1994 \text { so } \\
\text { that this citation matches the Reference List. Please confirm that this is } \\
\text { correct. }\end{array}$ & \\
\hline 9. & $\begin{array}{l}\text { AUTHOR: DeVaus } 2002 \text { has been changed to De Vaus } 2002 \text { so that this } \\
\text { citation matches the Reference List. Please confirm that this is correct. }\end{array}$ & \\
\hline 10. & $\begin{array}{l}\text { AUTHOR: 'Subjects' has been inserted after } 387 \text {. Please confirm if this is } \\
\text { correct. }\end{array}$ & \\
\hline 11. & $\begin{array}{l}\text { AUTHOR: Please give manufacturer information for SPSS Version 16.0: } \\
\text { company name, town, state (if USA), and country. }\end{array}$ & \\
\hline 12. & $\begin{array}{l}\text { AUTHOR: If Ashworth and Page } 2010 \text { has now been published online, } \\
\text { please add relevant year/DOI information. If this reference has now been } \\
\text { published in print, please add relevant volume/issue/page/year } \\
\text { information. }\end{array}$ & \\
\hline 13. & $\begin{array}{l}\text { AUTHOR: Kaiser, } 1974 \text { has not been cited in the text. Please indicate where } \\
\text { it should be cited; or delete from the Reference List. }\end{array}$ & \\
\hline 14. & $\begin{array}{l}\text { AUTHOR: Please provide the city of the publisher for reference Stevens } \\
1992 .\end{array}$ & \\
\hline
\end{tabular}




\begin{tabular}{|l|l|l|}
\hline 15. & $\begin{array}{l}\text { AUTHOR: Please provide the volume number for reference Yuksel and } \\
\text { Rimmington 1998. }\end{array}$ & \\
\hline 16. & AUTHOR: Please define KMO. & \\
\hline 17. & $\begin{array}{l}\text { AUTHOR: 'df' has been defined as 'degree of freedom'. Please confirm if } \\
\text { this is correct. }\end{array}$ & \\
\hline 18. & AUTHOR: Please define Sig and VIF. & \\
\hline 19. & AUTHOR: Please check and confirm if Table 5 has been styled correctly. & \\
\hline 20. & AUTHOR: Please give the full form of exp. & \\
\hline
\end{tabular}


Required Software to eAnnotate PDFs: Adobe Acrobat Professional or Acrobat Reader (version 8.0 or above). The Latest version of Acrobat Reader is free: http://www.adobe.com/products/acrobat/readstep2.html

Once you have Acrobat Reader 8, or higher, open on your PC you should see the Commenting Toolbar:

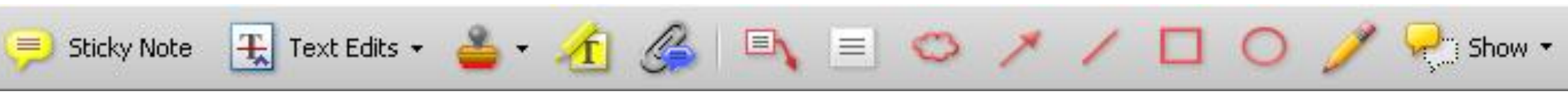

${ }^{\star \star \star *}$ (If the above toolbar does not appear automatically go to Tools>Comment \& Markup>Show Comment \& Markup Toolbar) ${ }^{\star \star \star \star}$

\section{Replacement Text Tool — For replacing text.}

Strikes a line through text and opens up a replacement text box.

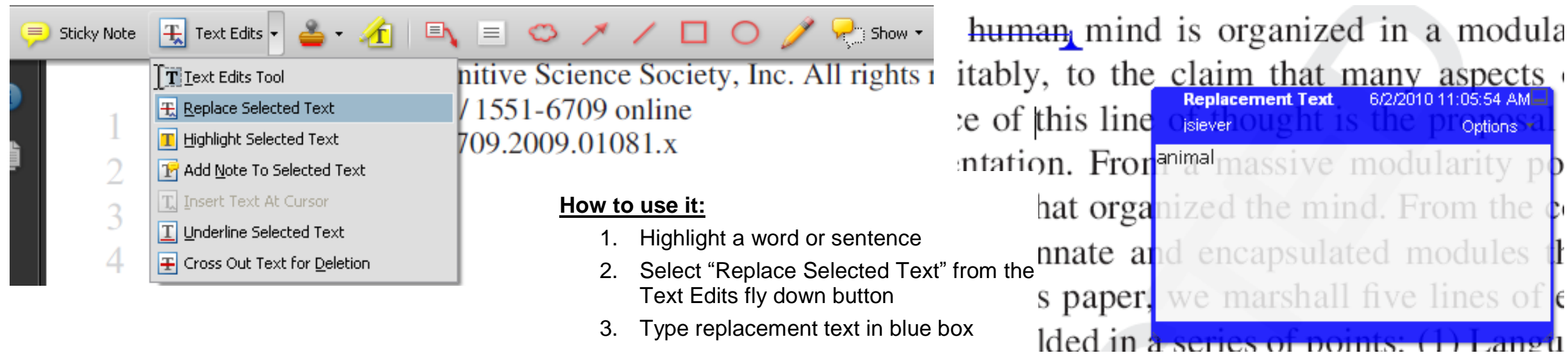

\section{Cross-out Text Tool — For deleting text.}

Strikes a red line through selected text.

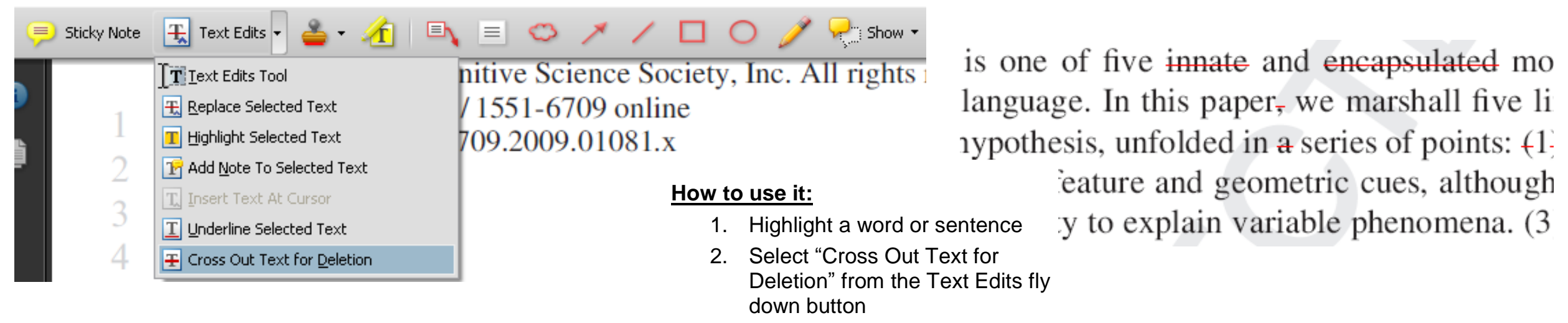

\section{Highlight Tool — For highlighting a selection to be changed to bold or italic.} Highlights text in yellow and opens up a text box.

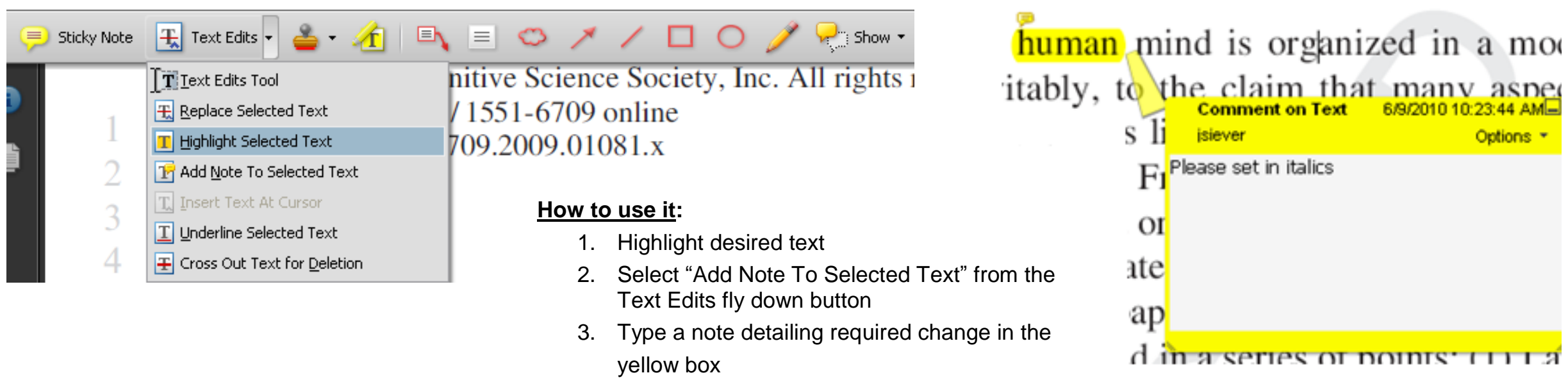

\section{Note Tool - For making notes at specific points in the text} Marks a point on the paper where a note or question needs to be addressed.

$\equiv$ Sticky Note Text Edits
How to use it:
1. Select the Sticky Note icon from the commenting toolbar
2. Click where the yellow speech bubble symbol needs to appear and a yellow
text box will appear
3. Type comment into the yellow text box

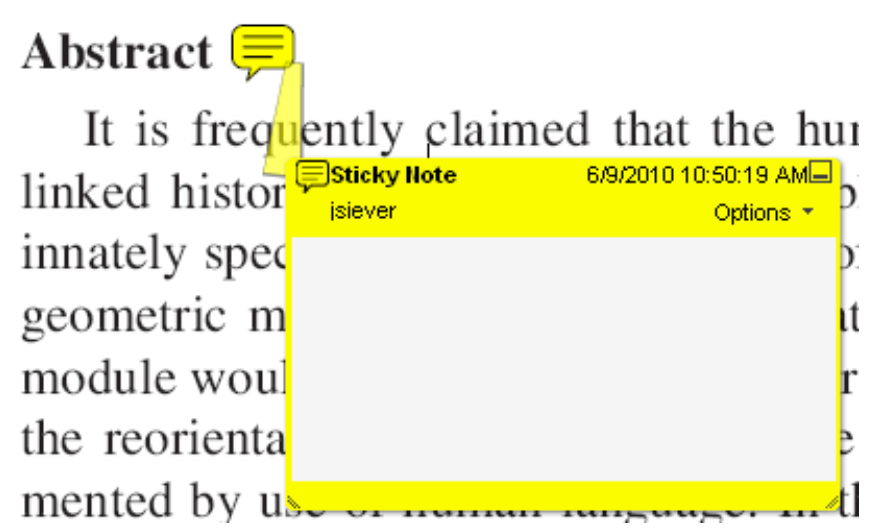




\section{Drawing Markup Tools - For circling parts of figures or spaces that require changes}

These tools allow you to draw circles, lines and comment on these marks.

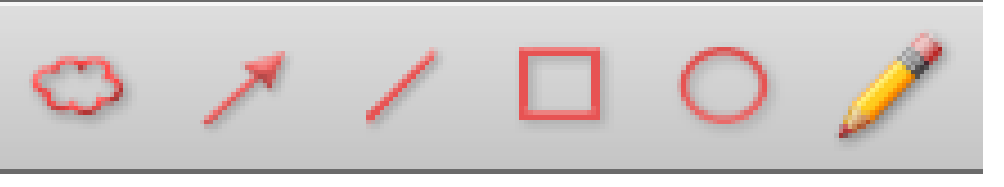

How to use it:

1. Click on one of shape icons in the Commenting Toolbar

2. Draw the selected shape with the cursor

3. Once finished, move the cursor over the shape until an arrowhead appears and double click

4. Type the details of the required change in the red box

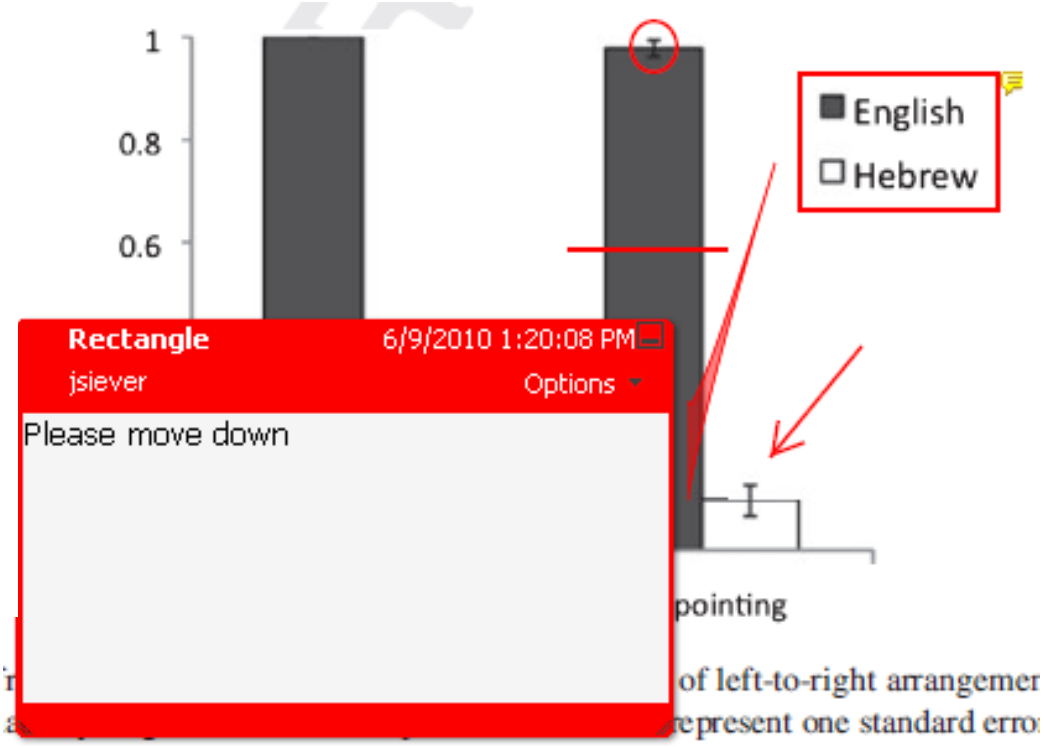

\section{Attach File Tool — For inserting large amounts of text or replacement figures as a files.} Inserts symbol and speech bubble where a file has been inserted.

\section{matter to be changed How to use it:}

matter to be clainged matter to be changed

1. Right click on the Commenting Toolbar

2. Select "Attach a File as a Comment"

3. Click on paperclip icon that appears in the natter to be changed Commenting Toolbar

4. Click where you want to insert the attachment

5. Select the saved file from your PC or network

6. Select type of icon to appear (paperclip, graph, attachment or tag) and close

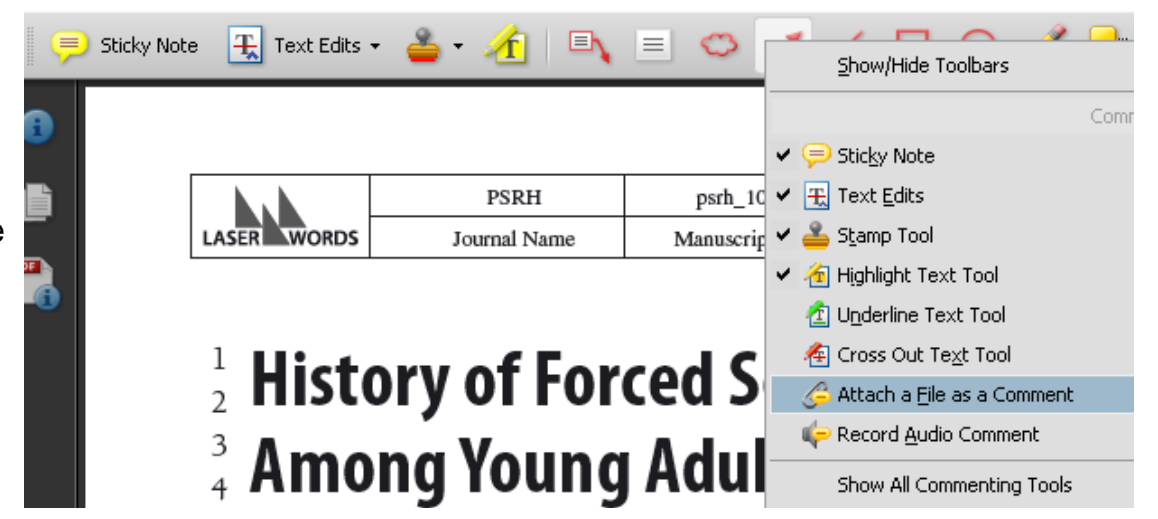

\section{Approved Tool (Stamp) — For approving a proof if no corrections are required.}

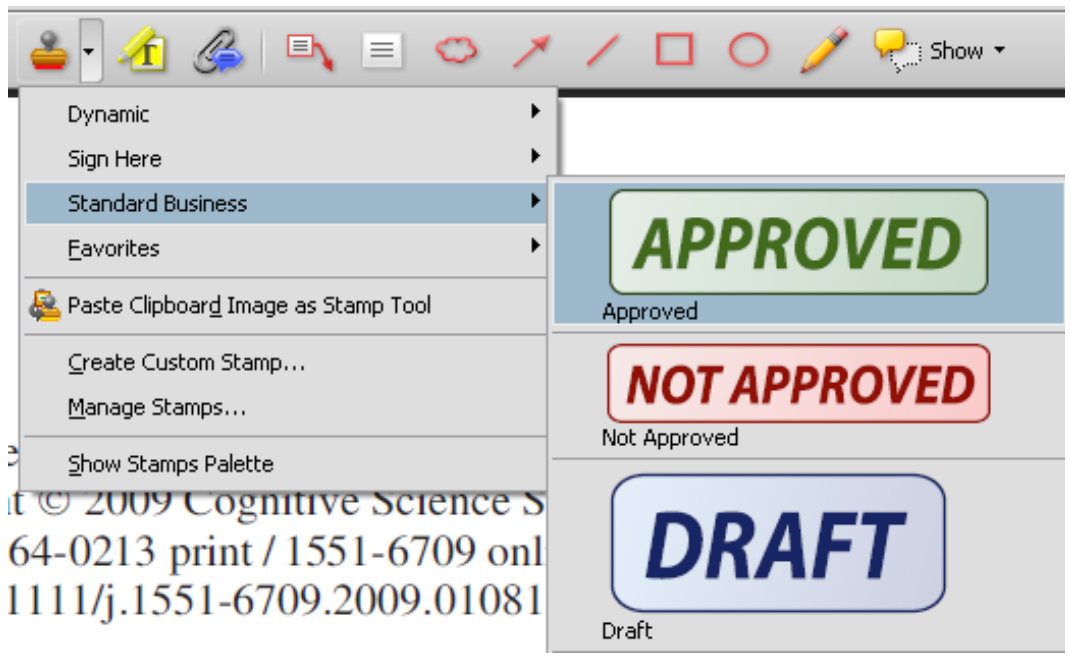

How to use it:

1. Click on the Stamp Tool in the toolbar

2. Select the Approved rubber stamp from the 'standard business' selection

3. Click on the text where you want to rubber stamp to appear (usually first page)

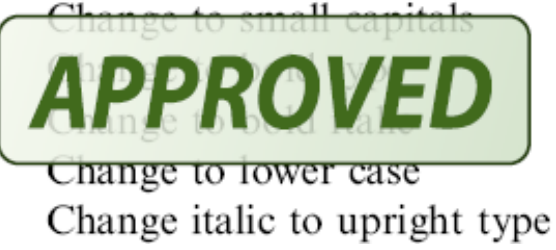

\section{Help}

For further information on how to annotate proofs click on the Help button to activate a list of instructions:

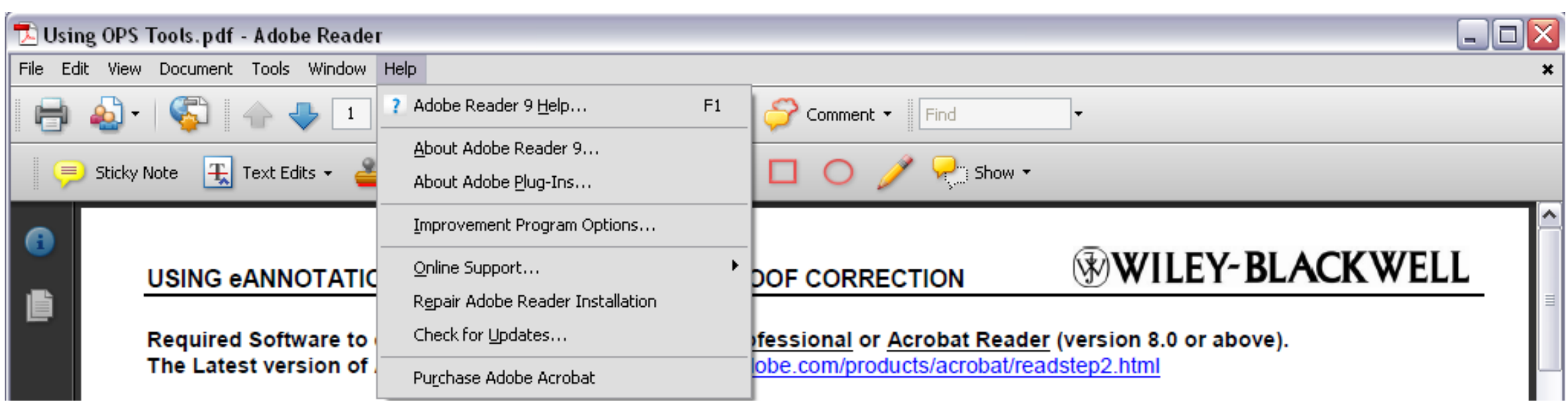

